\section{International Journal of Karamanoglu Mehmetbey Educational Research}

ULUSLARARASI

KARAMANOĞLU MEHMETBEY EĞITIM ARASTTIRMALARI DERGISİ

Cilt 3 -Özel Sayı 1 Eylül 2021

\title{
SALGIN DÖNEMİNDE UZAKTAN TÜRKÇE ÖĞRETİMİ: ÖĞRETMEN GÖRÜŞLERİ KAPSAMINDA BİR DEĞERLENDİRME
}

\section{THE TURKISH TEACHING IN THE EPIDEMIC PERIOD: AN ASSESS IN THE POINTS OF VIEW OF TEACHER'S ASPECT}

\begin{tabular}{|c|c|}
\hline & Özet \\
\hline $\begin{array}{l}\text { Karamanoğlu Mehmetbey } \\
\text { Uluslararası Eğitim } \\
\text { Araştırmaları Dergisi }\end{array}$ & $\begin{array}{l}\text { Beklenmedik bir biçimde tüm dünyayı etkisi altına alan koronavirüs salgınının, toplu ortamlarda bulunma yasaklarını } \\
\text { gündeme getirmesiyle dönem dönem Millı̂ Eğitim Bakanlığı tarafından uzaktan eğitim kararı alınmıştır. Bu çalışmada } \\
\text { salgın döneminde sürdürülen Türkçe derslerinin öğretmen görüşleri doğrultusunda değerlendirilmesi amaçlanmıștır. }\end{array}$ \\
\hline $\begin{array}{l}\text { Eylül, } 2021 \\
\text { Cilt 3, Sayı: Özel Sayı } \\
\text { Sayfalar: 55-65 } \\
\text { http://dergipark.gov.tr/ukmead }\end{array}$ & $\begin{array}{l}\text { Bu amaç doğrultusunda Türkçe öğretmenlerinin koronavirüs salgını sürecinde yaşadığı en önemli sorunlar ve bu } \\
\text { sorunlara yönelik çözüm önerilerine yer verilmiştir. Durum çalışması olarak desenlenen bu araştırmaya Adana ili } \\
\text { Ceyhan ilçesinde görev yapan ve gönüllülük esasına göre belirlenen } 50 \text { Türkçe Öğretmeni katılmış, veriler } 13 \text { madde } \\
\text { içeren yarı yapılandırılmış görüşme formu ile toplanmıştır. Verilerin değerlendirilmesi neticesinde; uzaktan eğitimle }\end{array}$ \\
\hline * Sorumlu Yazar & $\begin{array}{l}\text { yürütülen Türkçe derslerinde öğretmenlerin yazma becerisi ve dil bilgisi öğretiminde çok zorlandığı, EBA'daki Türkçe } \\
\text { ders içeriklerinin yetersiz olduğu, Türkçe ders kitaplarının uzaktan eğitime uygun olmadığı, öğretmenlerin \%90'ının } \\
\text { koronavirüs salgını öncesinde uzaktan eğitim tecrübesine sahip olmadığı gibi sonuçlara ulaşılmış ve bu doğrultuda } \\
\text { bazı önerilerde bulunulmuştur. }\end{array}$ \\
\hline DOI: $10.47770 /$ ukmead.985496 & \begin{tabular}{r|r} 
Anahtar \\
kelimeler:
\end{tabular} \mid Türkçe dersi, salgın, uzaktan eğitim. \\
\hline
\end{tabular}

\section{Abstract}

After coronavirus epidemic influenced all the world unexpectedly and started prohibition of being at crowded places Ministry of National Education has taken the decision of distance learning. The purpose of this study is to evaluate Turkish lessons studied during the pandemic periodin accordance with teachers' views. In line with this objective the most important problems teachers of Turkish experienced during the epidemic and solution suggestions for these problems have been discussed. We have chosen 50 teachers of Turkish who are still working in Ceyhan, Adana, and have determined them onvoluntary basis for this study where we have used case study. At the end of the evaluation of the data we have come to conclusion that teachers have too much difficulty in teaching writing and grammar in the Turkish lessons carried out distantly, that the content of Turkish lessons in EBA are insufficient, that the Turkish coursebooks are not suitable to distance teaching and that $90 \%$ of the teachers do not have experience for distance teaching before the coronavirus epidemic, and we have had some suggestions accordingly.

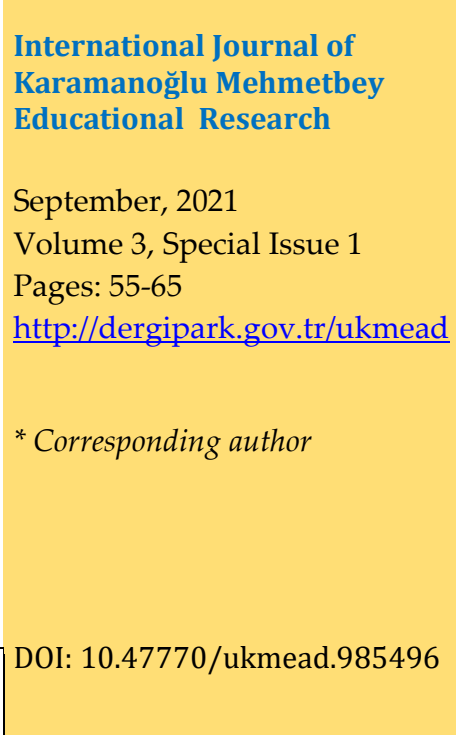

\footnotetext{
${ }_{1}$ MEB, s.kolcu24@gmail.com

${ }^{2}$ Hatay Mustafa Kemal Üniversitesi, Eğitim Fakültesi, abalci@mku.edu.tr
} 


\section{GİRIS}

Uzaktan eğitim, küresel olarak yaşanan salgın dönemiyle birlikte hayatımıza hızlı bir giriş yapsa da, aslında 1700'lerden bu yana mevcut olduğu için yeni bir olgu değildir. Uzaktan eğitimin ilk biçimi, yazışmalı okul modelidir. Uzaktan eğitim, öğretmen ve öğrenciler fiziksel uzaklıkla ayrıldığında gerçekleşir. İlk örnek olarak, Caleb Phillips, 20 Mart 1728'de Boston Gazetesi'ne, aday öğrencilere haftalık kısa dersler göndermeyi teklif eden bir ilan vermiş ve uzaktan öğrenmenin ilk öncüleri, herkes için öğrenme fırsatlarını artırma ihtiyacının farkına varmışlardır (Harting ve Erthal, 2005, s. 35). 1800'lerde yazışma okuluyla tarih, bilim, sanat gibi dersler verilmeye başlanmış ve yüzyılın sonuna doğru gelindiğinde güvenli posta ile teslimat teknolojileri ortaya çıktığından eğitim kurumları uzaktan eğitimi yaygınlaștırmaya bașlamıștır. İlk zamanlar uzaktan eğitim geleneksel olmayan bir eğitim yöntemiyken zamanla gelişmiş ve yaygın hâle gelmiştir (Banas ve Emory, 1998, s. 365). 1700'lerde uzaktan eğitimin emarelerini gösteren bu olayların; eğitimin amacına ulaştığını gösterir bir neticesi bilinmediğinden modern anlamda uzaktan eğitimin Isaac Pitman tarafından İngiltere'de 1840 yılında başlatıldığı kabul edilmektedir (Mshvidobadze ve Gogoladze, 2012, s. 134). Avrupa'da ise ilk zamanlarda uzaktan eğitim yine yazıșma kursları yoluyla yapılmış; bu durum, eğitici radyo ve televizyonun daha popüler hâle geldiği 20. yüzyılın ortalarına kadar uzaktan öğrenmenin birincil yolu olarak kalmıștır (Valentine, 2002, s. 1-11). 1960'lara gelindiğinde baskı, radyo, televizyon, ses ve video kasetleri, bilgisayar kullanımı gibi teknolojik ilerlemelerle uzaktan eğitim başka bir boyuta geçmiş ve çok daha kolaylaşmıştır. Teknolojinin uzaktan eğitim ile her zaman yakın bir ilişkisi olmuştur çünkü teknoloji öğretmen ve öğrenci arasındaki ayrıllğa aracılık eder (Sumner, 2000, s. 267,282). Ülkemizde uzaktan eğitim serüvenine bakıldığında Cumhuriyet'in ilk dönemlerinde, eğitimli nüfusun çoğunluğu uzun süren savaş dönemlerinde kaybedildiğinden, hızlı bir kalkınma için eğitimli kişilere ihtiyaç duyulması sebebiyle öncelikli konulardan biri eğitim-öğretim olmuş ve bu sebeple uzaktan eğitim konusu tartışılmaya başlanmıştır. 1923'ten 1956'ya dek süren tartışma döneminin ardından mektupla yazışarak uzaktan eğitim çalışmaları başlamış, 1976-1995 yılları arasında radyo ve televizyon gibi görsel-işitsel araçlarla devam etmiş, 1996 sonrası ise bilişim tabanlı olarak internet üzerinden sürdürülmeye devam edilmiştir (Bozkurt, 2017, s. 86-88).

Ülkemizde yaygın olarak bilinen, uzaktan eğitim yönteminin kullanıldığı örgün öğretim faaliyetlerinden farklı olarak açlk öğretim uygulamaları bulunmaktadır. "Açık öğretim, öğretici ile öğrenicinin bir arada bulunma zorunluluğunu ortadan kaldıran öğretim faaliyetleri sisteminin adıdır. Herhangi bir şekilde örgün öğrenime devam edemeyen öğrencilerin eğitim-öğretim faaliyetlerinden uzak kalmamak için başvurduğu ve oldukça yoğun şekilde talep edilen bu sistem ortaokul, ortaöğretim, yükseköğretim düzeylerinde faaliyet göstermektedir" (Bulut, 2020, s. 933).

Koronavirüs salgını öncesinde farklı amaç ve politikalarla kullanılan uzaktan eğitim, salgınla birlikte örgün eğitimin de temel taşı hâline gelmiştir. Bu durum gerek öğretmen gerekse öğrenciler tarafından teknoloji kullanımında bir sıçramaya neden olmuştur. Örgün eğitimde teknoloji kullanımı, ülkemizde 2000'li yılların sonuna doğru yaygınlaşmaya başlamıştır. Salgının, toplu ortamlarda bulunma yasaklarını gündeme getirmesiyle birlikte tüm eğitim kademelerinde dönem dönem, Millî Eğitim Bakanlığı tarafından uzaktan eğitim kararı alınmış; normal eğitim sürecinde ihtiyaç duyulan teknoloji kullanımının çok daha fazlası uzaktan eğitim sürecinde temel ihtiyaç ve temel araç haline gelmiştir. Eğitim sistemimizin öğrenci merkezli öğretimi temel alması, öğretmenlerin öğrencilere karşı yol gösterici konumda olmasını gerektirmektedir. Öğrencilere, öğretmenler tarafından bilginin hazır olarak sunulması yerine; öğretmenler, bilgiyi öğrencilerin kendilerinin yapılandırmalarına yardım etmelidirler (Güneş, 2009, s. 19). İyi bir yol göstericinin, günümüz dünyasında teknoloji alanında kendini geliştirmiş olması ise bir gerekliliktir. Bu kritik salgın dönemine dek gereklilik hâlinde olan eğitimde teknoloji kullanımı, artık bir zorunluluk hâline gelmiştir.

Teknolojinin hızla gelişmiş olması uzaktan eğitim sürecinde kolaylıklar sağlasa da uzaktan eğitime dair yapılan çalıșmalarda örgün eğitime kıyasla birçok avantaj ve dezavantajlara rastlanmaktadır. Dünya Sağlık Örgütü'nün koronavirüsü salgın hastalık olarak nitelendirdiğinden bu yana dünyada 290 milyondan fazla öğrenci okullarına ara vermiş, ve uzaktan eğitim yoluyla eğitim-öğretime devam etmek durumunda kalmıștır. Şu anda ise yaklaşı 120 milyon öğrenci bu durumdan olumsuz etkilenmeye devam etmektedir (UNESCO, 2021). Bu sebeple uzaktan eğitim kişisel bir seçim veya politik bir karardan ziyade gerekliliktir. Doğal afet ve salgın gibi olağanüstü durumlarda seçim şansı olmadığından uzaktan eğitime dair olumlu ve olumsuz yönlerin eğitim modelinin seçilmesine etkisi olmayacaktır. İçinde bulunulan ve ülkemizde Mart 2020'den beri devam eden bu durum eğitim-öğretimin her kademesini ve tüm dersleri etkilediği gibi Türkçe derslerini de çeşitli değişkenler bakımından etkilemiştir. Türkçe dersleri okuma, dinleme, konuşma, yazma becerileri ve dil bilgisi içeriği ile geniş bir alanı kapsamaktadır. Türkçe öğretiminin temel hedeflerinden biri; "öğrencilerin hayat boyu kullanabilecekleri dinleme/izleme, konuşma, okuma ve yazma ile ilgili dil becerilerini ve zihinsel becerileri kazanmaları, bu becerileri kullanarak kendilerini bireysel ve sosyal yönden geliştirmeleri" (MEB, 2019, s. 8) ve bununla birlikte etkili bir iletişim kurmalarını sağlamaktır. Ana dili bilgi ve becerisinin kazandırılmasında yeri ve zamanı geldikçe uygun yöntem ve ortamlar oluşturularak eğitim-öğretim yapılmalıdır (Demir ve Yapıcı, 2007, s. 180). Uzaktan eğitimin eğitim-öğretimde tek seçenek olduğu salgın döneminde öğrenciler için en verimli öğretimin yapılması için Türkçe öğretiminin uzaktan eğitim sürecindeki durumunun araștırılması, bu dönemde yaşanan sorunların, olumlu ve olumsuz durumların belirlenmesi bundan sonraki sürecin olumsuzluklardan arındırılmış bir şekilde gelişerek devam etmesi adına önem arz etmektedir.

\section{Araștırmanın amacı}

Çalışmanın amacı salgın döneminde sürdürülen Türkçe derslerinin öğretmen görüşleri doğrultusunda değerlendirilmesidir. Bu amaç doğrultusunda; en çok hangi beceri öğretiminde zorlanıldığı, öğrencilerin Türkçe dersine olan ilgileri, EBA Türkçe dersi 
içeriği, Türkçe derslerine katılım oranı, Türkçe ders kitaplarının uzaktan eğitime uygunluğu, Türkçe öğretmenlerinin salgın öncesi uzaktan eğitim tecrübeleri ve bilgileri, Türkçe öğretmenlerinin teknoloji konusundaki bilgileri ve teknoloji kullanımları, Türkçe öğretmenlerinin yaşadığı en önemli sorunlar ve çözüm önerileri hakkında sorulara yanıt aranmıştır.

\section{YÖNTEM}

Bu bölümde araştırmanın modeli, çalışma grubu, veri toplama araçlarına ve verilerin analizine yer verilmiştir.

\section{Araştırmanın Modeli}

$\mathrm{Bu}$ araştırma durum çalışması deseni kullanılarak gerçekleştirilmiştir. Durum çalışmalarında "tek bir durumu veya az sayıdaki durumu yakından veya derinlemesine anlama ve ortaya çıkarma isteği” (Yin, 2017, s.4) ön plandadır. Bu durum hem nitel hem de nicel araştırmaların desenlenmesinde sıklıkla tercih edilebilmektedir.

\section{Çalışma Grubu}

Araştırma amacına uygun olarak çalışma grubu amaçlı örnekleme ile belirlenmiştir. Amaçlı örneklemede araştırmacılar ana olgu hakkında bilgi edinmek veya onu anlamak için bireyleri ve araştırma mekanlarını maksatlı bir biçimde seçerler (Cresswell, 2019, s. 266,267). Uzaktan eğitim sürecinde Türkçe dersleri hakkında detaylı bilgi edinmek amacıyla seçilen araştırmanın çalışma grubu Adana ili Ceyhan ilçesinde görev yapan ve araştırmaya gönüllü olarak katılan 50 Türkçe öğretmeninden oluşmuştur. Katılımcılardan 8'i özel okul, 42'si ise devlet okulunda görev yapmaktadır.

\section{Veri Toplama Araçları}

Araştırma verileri, araştırmacı tarafından hazırlanan ve 13 madde içeren yarı yapılandırılmış görüşme formu ile toplanmıştır. Görüşme formu üç alan uzmanı tarafından incelenmiş, gerekli düzenlemeler yapıldıktan sonra forma son hâli verilmiştir. Yarı yapılandırılmış görüşme formu hazırlanırken, salgın dolayısıyla tüm görüșmelerin yüz yüze yapılamayabileceği de hesaba katılarak soruların açık ve anlaşılır olmasına dikkat edilmiştir. Çalışma sırasında, İlçe Millî Eğitim Müdürlüğünden gerekli izinler alınsa da çalışmanın gönüllülük esasına dayalı olduğu belirtilmiştir. Katılımcılar, ilçe merkezi, köyler veya özel okullar şeklinde ayrım yapılmaksızın seçilen tüm ilçe okullarından gönüllü olan öğretmenlerdir. Görüşme formu uygulanırken araştırmacı (bu makalenin birinci yazarı), kişisel görüşmeye müsaade edilmeyen okullar hariç, katılımcılarla görüşmüştür. Salgın dolayısıyla çeşitli sebeplerle görüşme ortamının sağlanamadığı okullara araştırmacının iletişim bilgileri bırakılmış, soruları olan katılımcılar araştırmacıya ulaşabilmiştir.

\section{Verilerin Analizi}

Çalışmada elde edilen veriler betimsel analiz ve içerik analizi kullanılarak değerlendirilmiştir. İçerik analizi, toplanan verilerin derinlemesine analiz edilmesini gerektirir ve önceden belirgin olmayan temaların ve boyutların ortaya çıkarılmasına olanak tanır (Sözbilir, 2009, s. 9). Bu araştırmada da öğretmenlerin görüşleri neticesinde ortaya çıkan tema ve boyutlar, frekans ve yüzde alınarak tablolaştırılmış ve yorumlanmıştır. Araştırmaya katılan Türkçe öğretmenlerinin görüşlerinden kesitlere, bulgular kısmında doğrudan alıntı yapılarak yer verilmiştir. Katılımcılar Ö1 (öğretmen 1), Ö2, Ö3,... şeklinde kodlanmıştır.

Araştırmanın bulguları, yarı yapılandırılmış görüşme formunda yer alan 12 soru ile katılımcıların eklemek istedikleri konular için açık uçlu olarak bırakılan 1 maddeden (toplam 13 madde) oluşmaktadır. Öğretmenlerin sorulara verdikleri yanıtlar öncelikle genel olarak tablolaştırılmış, görüşlerin bir kısmı açıklamalara eklenip var olan durum örneklendirilerek ortaya konmuştur.

\section{BULGULAR}

Çalışma grubunda yer alan Türkçe öğretmenlerinin veri toplama aracında bulunan sorulara verdikleri yanıtlardan oluşan bulgular gruplandırılarak bu bölümde sunulmuştur:

\subsection{Uzaktan Türkçe Öğretiminde Hangi Beceri/Alan Öğretiminde Zorlanıldığına Dair Görüşler}

$\mathrm{Bu}$ başlık altında ortaya konan bulgulara, görüşme formunda öğretmenlere yöneltilen "Uzaktan eğitimle yapılan Türkçe derslerinde hangi beceri/alan (okuma, dinleme, konuşma, yazma, dil bilgisi) öğretiminde zorlandınız? Açıklayınız." sorusu yöneltilmiştir. Bu soruya verilen yanıtlar öncelikle Tablo 1'de genellenerek sunulmuş, ardından öğretmen görüşlerinden doğrudan alıntılar yapılarak örneklere yer verilmiştir. 
Tablo 1.

Uzaktan Türkçe Öğretiminde Zorlanılan Alan ve Beceriler

\begin{tabular}{lll}
\hline Beceri/Alan & $f$ & $\%$ \\
\hline Okuma & 8 & 10,6 \\
Yazma & 31 & 41,3 \\
Konuşma & 9 & 12 \\
Dinleme & 7 & 9,3 \\
Dil Bilgisi & 20 & 26,6 \\
\hline Toplam & 75 & 100 \\
\hline
\end{tabular}

Tablo 1'e bakıldığında Türkçe öğretmenlerinin uzaktan Türkçe öğretiminde en çok zorluk yaşadığı beceri \%41,3 oranla yazma becerisidir; en az zorluk yaşanan beceri ise \%9,3 oranla dinleme becerisidir. Öğretmenlerin büyük bir kısmı birkaç beceride birden zorlandıklarını ifade etmişlerdir. Araştırmaya katılan yalnızca bir öğretmen (Ö5) hiçbir beceri ve alanda zorluk yaşamadığını belirtmiştir. Araştırmaya katılan öğretmenlerden;

Ö3. "Denetim ve düzeltme imkânı sınırlı olduğu için en çok yazmada zorlandım."

Ö19. "Konuşma esnasında öğrencilerin jest ve mimiklerini takip etmek mümkün olmadiğından konuşma becerisi öğretiminde zorlandım."

Ö21. "Dinleme becerisinde zorlandım, çünkü öğrenciler hep bir ağızdan konuşuyorlar."

Ö22. "Yazma becerisi öğretiminde zorlandım. Çünkü 30 dakikalık ders süresi yazma becerisi öğretiminde oldukça kısa bir süre."

Ö35. "Tüm alanlarda takip ve değerlendirme noktasında zorlandım."

Ö50. "Uzaktan eğitim Türkçe dersinde en çok yazma öğretiminde zorlandım. Konu anlatımında mutlaka yazı yazarak öğrencilere not aldırıyoruz. Bilgisayarda yazı yazmak tahtada yazı yazmaya hiç benzemiyor. Yazı yazmanın güçlüğü aynı zamanda ders anlatımında zaman kaybının yaşanmasına da neden oluyor. Okuma, dinle, konuşma öğretimlerinde bağlantı sorunu yaşamadığım sürece herhangi bir problemle karşılaşmadım."

şeklinde görüşlerini sunmuşlardır. Araştırmaya katılan öğretmenlerin bu soruya verdikleri yanıtlar incelendiğinde beceri/alan öğretiminde zorluklar yaşanmasının temel sebebi olarak öncelikle zaman kısıtlılı̆̆ı yer almaktadır. Öğrencilerin kamera açma zorunluluğu olmaması, öğretmen öğrenci etkileşimini kısıtlayarak uzaktan Türkçe öğretiminde zorluklara sebebiyet vermiştir.

\subsection{Uzaktan Eğitimin Öğrencilerin Türkçe Dersine Olan İlgilerine Etkisi}

Araştırmaya katılan Türkçe öğretmenlerine "Uzaktan eğitim, öğrencilerin Türkçe derslerine olan ilgilerini etkiledi mi? Örneklendiriniz." sorusu yöneltilmiştir. Verilen yanıtlar doğrultusunda aşağıdaki sonuçlara ulaşılmıştır:

Tablo 2.

Uzaktan Ĕ̆itimin Öğrencilerin Türkçe Dersine Olan İlgilerine Etkisi

\begin{tabular}{lll}
\hline Etki Durumu & $f$ & $\%$ \\
\hline Var & 38 & 76 \\
Yok & 12 & 24 \\
\hline Toplam & 50 & 100 \\
\hline
\end{tabular}

Türkçe öğretmenleri \%76'lık bir oranla uzaktan eğitimin öğrencilerin Türkçe derslerine olan ilgisini etkilediğini belirtmişlerdir. Araştırmaya katılan öğretmenlerden bir kısmı uzaktan eğitimin öğrencilerin Türkçe dersine olan ilgilerini olumlu yönde etkilediğini, bir kısmı olumsuz yönde etkilediğini, bir kısmı da hem olumlu hem de olumsuz etkilerin zamanla yer değiştirerek bir arada görüldüğünü belirtmişlerdir. Dolayısıyla uzaktan eğitimin Türkçe dersine olan ilgiyi yalnızca olumsuz yönde etkilediği düşünülmemelidir. Bu soruya verilen bazı öğretmen görüşleri şu şekildedir:

Ö2. "Bazı öğrencilerde olumlu etkiledi. Daha çok görsel, etkinlik vb. kullanılması derse ilgiyi olumlu etkilemiştir. Bununla birlikte uzaktan eğitim bazı öğrencilerde 'olmasa da olur, katılmasam da olur' düşüncesi oluşturdu."

Ö14. "Yaparak yaşayarak öğrenme etkinliklerini yapamadığımız için öğrencilerin ilgileri azaldı.".

Ö15. "Sınıf içinde yapılan fiziksel aktiviteler, bilişsel ve duyuşsal olarak çocuklara daha çok etki ettiği için bunları uzaktan yapamadık. Bu durum da çocukları olumsuz etkiledi."

Ö33. "Bazı öğrencilerim okuldaki performanslarına göre uzaktan eğitimde daha başarılıydılar."

Ö41. "Evet, ilgilerini etkiledi. İlk başlarda derse katılmak istemediler veya uzaktan eğitimle yapıldı̆̆ için dersleri ders olarak görmediler. Sonraları akademik başarı düzeyi düşük öğrenciler bile derse katılmaya başladı. Teknolojiyle iç içe bir eğitim olması ilgilerini çekti." 


\subsection{EBA Türkçe Dersi İçeriğinin Yeterliliğine Dair Görüşler}

Katılımcı Türkçe öğretmenlerine, EBA Türkçe dersi içeriğini yeterli bulup bulmadıkları ve nedenleri sorulmuştur. Verilen yanitlara göre ulaşılan sonuçlar Tablo 3'te sunulmuştur:

Tablo 3.

EBA Türkçe Dersi İçeriğinin Yeterliliği

\begin{tabular}{lll}
\hline & $f$ & $\%$ \\
\hline Yeterli & 19 & 38 \\
Kısmen Yeterli & 4 & 8 \\
Yeterli Değil & 27 & 54 \\
\hline Toplam & 50 & 100 \\
\hline
\end{tabular}

Millî Eğitim Bakanlığının 2012 yılında öğrenci ve öğretmenlerin kullanımına sunduğu EBA platformu zamanla gelişme göstermiştir. Uzaktan eğitimde ders sürelerinin azaltılması sebebiyle EBA öğrencilerin ders içeriklerine ulaşmada başlıca yöneldikleri platform olmuştur. Araştırmaya katılan Türkçe öğretmenlerinin \%54'ü kuruluşundan bu yana uzun bir süre geçmiş olan EBA platformunun içeriğini yeterli bulmadığını ve geliştirilmesi gerektiğini düşünmektedir. Araştırmaya katılan 4 öğretmen Türkçe ders içerikleri açısından EBA'yı kısmen yeterli bulurken 19 öğretmen de yeterli düzeyde bulmuştur. Uzaktan eğitimde EBA tüm okullarda temel canlı ders işleme programı olmuştur. Ancak salgın sebebiyle uzaktan eğitime geçiş ani olduğundan sistem yoğun kullanıldığında zaman zaman sistemde birtakım aksaklıklar oluşmuştur. Bu durum tüm derslerde olduğu gibi Türkçe derslerine de olumsuz yansımıştır. Öğretmenlerin bazılarının EBA Türkçe ders içerikleri hakkında görüşleri şu şekildedir:

Ö1. "EBA içerikleri hazırlanış tekniği bakımından oldukça iyi ve çeşitli."

Ö3. "EBA Türkçe dersi içeriğini yeterli bulmuyorum. Özellikle dinleme ve yazma becerilerini geliştirecek etkinlikler çoğaltılmalı."

Ö22. "EBA Türkçe dersi içeriğinde özellikle 8. sınıf öğrencileri için büyük eksiklikler var. İçerikler (sınav, test, konu anlatımı vs.) çok yüzeysel ve amaca ulaşmaktan uzak."

Ö35. "EBA'nın güncellenmesi gerektiğini düşünüyorum. Ayrıca çoktan seçmeli sınavlara yönelik içerikler artırılmall, çünkü Türkiye genelinde sınavlar her zaman çoktan seçmeli yapıliyor."

Ö38. "EBA'yı yeterli bulmuyorum, bazı soruların cevaplarını yanlış açıklıyor."

Ö50. "Açıkça söylemek gerekirse EBA'yı çok fazla takip etmedim. Ama EBA için duyduklarım sistemin başarısız ve yetersiz oluşu. En çok yaşanan sorunlardan birisinin sisteme fazla giriş olduğunda sistemin çökmesi ve öğrencilerin bundan dolayı mağdur oluşu."

\subsection{Uzaktan Eğitimle Yapılan Türkçe Derslerine Katılım Oranının Diğer Derslere Oranı}

Katılımcılara yöneltilen "Uzaktan eğitimle gerçekleştirilen Türkçe derslerine katılım diğer derslere oranla ne durumdadır?" sorusuna ait cevaplar incelendiğinde Tablo 4'teki genel görünüm ortaya çıkmaktadır.

Tablo 4.

Uzaktan Eğitimle Yapılan Türkçe Derslerine Katılımın Diğer Derslere Oranı

\begin{tabular}{lll}
\hline Katılım & $f$ & $\%$ \\
\hline Yüksek & 18 & 36 \\
Eşit & 26 & 52 \\
Düşük & 6 & 12 \\
\hline Toplam & 50 & 100 \\
\hline
\end{tabular}

Türkçe öğretmenlerinin görüşleri incelendiğinde uzaktan eğitim yoluyla gerçekleştirilen Türkçe derslerine katılımın diğer derslere olan katılımla kıyaslandığında \%52 oranıyla eșit düzeyde katılım olduğu sonucu ortaya çlkmıştır. 18 Türkçe öğretmeni katılımın diğer derslere olan katılıma oranla daha yüksek olduğunu, 6 Türkçe öğretmeni ise daha düşük olduğunu belirtmiştir. Bunun yanı sıra katılımcıların görüşlerine göre okuldaki toplam öğrenci sayısı dikkate alındığında uzaktan eğitime katılımın çok düşük oranda olduğu sonucuna da ulaşılmaktadır. Ancak, bu noktada özel okullar ile devlet okulları arasında derse katılım oranı bakımından ciddi düzeyde farklılık görülmektedir. Türkçe öğretmenlerinin öğrencilerin derse katılımıyla ilgili görüşlerinden bazıları aşağıda verilmiştir.

Ö1. "Okulumuzun özel okul olması, öğrencilerimizin her türlü donanıma ulaşabilmesindeki kolaylıklar, ders takip sistemimiz, programlama, ödevlendirme, proje çalışmaları ve deneme sınavlarımızın sıklığı dolayısıyla Türkçe dersine katılım oranı \%98'i geçmektedir."

Ö2. "Diğer derslere katılımla farkı yok. Ancak genel olarak derslere katılım bütün derslerde olduğu gibi \%40'ları geçmiyor."

Ö5. "Türkçe dersine katılım diğer derslere oranla daha yüksek. Türkçe dersini öğrenciler önemsemektedir."

Ö18. "Okulumuzda müzik, resim, beden eğitimi derslerine katılım Türkçe dersine göre daha fazladır." 


\subsection{Türkçe Ders Kitaplarının Uzaktan Eğitime Uygunluğuna Dair Öğretmen Görüşleri}

Türkçe öğretmenlerine Türkçe ders kitaplarının ve içeriklerinin uzaktan eğitime uygunluğu ve varsa önerileri sorulmuştur. Bu soruya verilen cevaplardan elde edilen sonuçlar Tablo 5'te sunulmuştur:

Tablo 5.

Türkçe Ders Kitapları ve İçeriklerinin Uzaktan Eğitime Uygunluğu

\begin{tabular}{lll} 
& $f$ & $\%$ \\
\hline Uygun & 15 & 30 \\
Uygun Değil & 35 & 70 \\
\hline Toplam & 50 & 100 \\
\hline
\end{tabular}

Araştırmaya katılan 50 öğretmenden 35'i Türkçe ders kitaplarını ve içeriklerini uzaktan eğitime uygun bulmamaktadır. Neden olarak ise çoğunlukla, kitapların yüz yüze eğitime uygun şekilde hazırlanması, uzaktan eğitimle yapılan Türkçe ders sürelerinin Türkçe kitaplarındaki etkinliklerin tamamını yapmaya yetmemesi görüşü öne çlkmaktadır. Katılımcı öğretmenlerden 15'i Türkçe ders kitaplarının hem uzaktan eğitimde hem de yüz yüze eğitimde rahatlıkla kullanılabileceğini belirtmiştir. Katılımcıların yöneltilen soruya verdikleri cevaplardan örnekler aşağıda sunulmuştur.

Ö1. "Çok da uygun olduğu söylenemez. Metinler daha kısa olmalı, yapılacak etkinlikler uzaktan eğitime uygun düzenlenmeli, kazanım sayısı azaltılmalı, sınava odaklı soru ve metinlerde ögrencilerin denizde tane aramalarını hatırlatan soru tiplerinden vazgeçilmeli."

Ö21. "Türkçe ders kitapları ve içerikleri uzaktan eğitime uygun ancak okuma metinleri seslendirilebilir."

Ö22. "Türkçe ders kitaplarını ve içeriklerini uzaktan eğitime uygun bulmuyorum. Özellikle uzaktan eğitim için Türkçe ders kitapları teknoloji tabanlı hazırlanmalı, zengin içeriğe sahip olmalı ve öğrencinin uzaktan eğitime katılımını teşvik edici donanimda olmall."

Ö35. "Türkçe ders kitapları uzaktan eğitimde kullanılabiliyor ancak EBA ile etkileşimi hâle getirilebilir. Z kitap şeklinde sunulabilir."

Ö39. "Pek uygun bulmuyorum. Görsel, özellikle dijital materyal kullanımı daha etkili oluyor. Paylaşımı kolay. Ders kitaplarının basılı materyal değil de dijital olması, içeriğinin öğretmen tarafından kısmen de olsa değiş̧tirilebilir olması çok iyi olurdu."

Ö41. "Uygun değil. Etkinlikler çok uzun ama ders süresi kısıtlı. Türkçe ders kitapları uzaktan eğitime uyarlanmalı."

\subsection{Koronavirüs Salgını Öncesi Öğretmenlerin Uzaktan Eğitim Tecrübeleri ve Görüşler}

Araştırmaya katılan Türkçe öğretmenlerine koronavirüs salgını öncesinde uzaktan eğitim yoluyla ders vermiş veya almış olma durumlarına ilişkin yöneltilen soruya verilen cevaplar Tablo 6'da gruplandırılarak verilmiştir:

Tablo 6.

Türkçe Öğretmenlerinin Salgın Öncesi Uzaktan Eğitim Tecrübeleri

\begin{tabular}{lll}
\hline & $f$ & $\%$ \\
\hline Tecrübesi Var & 5 & 10 \\
Tecrübesi Yok & 45 & 90 \\
\hline Toplam & 50 & 100 \\
\hline
\end{tabular}

Tablo 6 incelendiğinde Türkçe öğretmenlerinin \%90'ının uzaktan eğitim tecrübesine sahip olmadıkları görülmektedir. 50 öğretmenden yalnızca 5'i uzaktan eğitimle ders almış veya vermiştir.

\section{7. Öğretmenlerin Uzaktan Eğitime Yönelik Eğitim Alma Durumları ve Görüşler}

Türkçe öğretmenlerine uzaktan eğitime dair herhangi bir eğitim alıp almadıkları sorulmuştur. Verilen yanıtlar Tablo 7'de gösterilmiştir.

Tablo 7.

Türkçe Öğretmenlerinin Uzaktan Eğitime Yönelik Eğitim Alma Durumları

\begin{tabular}{lll}
\hline & $f$ & $\%$ \\
\hline Ĕ̈itim Almıș & 3 & 6 \\
Eğitim Almamıș & 47 & 94 \\
\hline Toplam & 50 & 100 \\
\hline
\end{tabular}

Mart 2020'de ülke genelinde uzaktan eğitime geçilmiştir. Ancak bu araştırmadan elde edilen sonuçlar Türkçe öğretmenlerinin \%94'ünün uzaktan eğitime dair herhangi bir eğitim almadı̆̆ını göstermektedir. Eğitim aldığını beyan eden öğretmenler ise kendi kendilerini eğittiğini, profesyonel düzeyde bir eğitim almadıklarını belirtmişlerdir. Araştırmaya katılan Türkçe öğretmenlerinin çoğunluğu herhangi bir eğitim almadığı hâlde uzaktan eğitim vermek durumunda kalmıştır. Bu açıdan bakıldığında eğitim almamış öğretmenler tarafından verilen uzaktan eğitimin hem öğretmen hem de öğrenci açısından sıkıntıların yaşanmasına sebebiyet verdiği söylenebilir. Ö41; "Uzaktan eğitime dair herhangi bir bilgim yoktu, eğitim de almadım. Aslında herkese eğitim verilebilirdi. Hem öğretmen hem de öğrencilere. Uzun süre boyunca bu işi kendi çabalarımızla öğrenmeye ve 
öğrencilere de öğretmeye çalıştık." şeklinde görüşünü dile getirmiştir. Uzaktan eğitime dair herhangi bir eğitim almadığını belirten Ö1 ise "Mutlaka bir eğitim almak gerektiğine inanıyorum, hatta üniversitelerde uzaktan eğitim dersi adı altında bir ders konmalıdır." diyerek düşüncesini dile getirmiştir.

\section{8. Öğretmenlerin Uzaktan Eğitimde Teknoloji Kullanımındaki Yeterliliklerine Dair Görüşler}

Uzaktan eğitim günümüzde büyük oranda teknoloji tabanlı olarak yürütüldüğünden araştırmaya katılan Türkçe öğretmenlerine teknoloji kullanımı hususunda kendilerini yeterli görüp görmedikleri sorulmuştur. Tablo 8'de verilen yanıtların sıklığı görülmektedir.

Tablo 8 .

Türkçe Öğretmenlerinin Teknoloji Kullanımındaki Yeterliliği

\begin{tabular}{lll} 
& $f$ & $\%$ \\
\hline Yeterli & 20 & 40 \\
Yetersiz & 30 & 60 \\
\hline Toplam & 50 & 100 \\
\hline
\end{tabular}

Katılımcların \%60'ı teknoloji kullanımında kendini yetersiz bulmaktadır. Teknoloji kullanım düzeyini yeterli bulan 20 öğretmenden bir kısmı bu süreçte kişisel çabalarıyla yeterliliklerini geliştirdiklerini ve süreç içerisinde yeterli düzeye geldiklerini belirtmişlerdir. Öğretmenlerin teknoloji kullanımındaki yeterliliği ile ilgili görüşlerden bazıları aşağıda sunulmuştur:

Ö1. "Kendimi yeterli bulmuyorum. Bilişim teknolojileri dersinin sadece ortaokul ile sınırlı kalmaması gerektiğine inanıyorum."

Ö22. "Teknoloji kullanımı hususunda kendimi yeterli bulmuyorum. Teknoloji adeta yaşayan bir olgu. Teknolojiyi takip etmek ve ona ayak uydurabilmek biz öğretmenler için çok büyük maddi külfet demek. Düşük maddi gelire sahip olduğumuzdan bu konuda kendimizi geliștirme imkânımız maalesef kısıtlıdır."

Ö33. "Kendimi yeterli bulmuyorum. Çünkü Zoom programı İngilizce olduğu için zorlandım."

Ö36. "Teknoloji konusunda çok iyi değildim ama iş başa düşünce insan her şeyi öğreniyor. Internette her şeyin açıklamalı videoları var."

\section{9. Öğretmenlerin Lisans Düzeyinde Türkçe Öğretimi ve Teknoloji Kullanımıyla İlgili Eğitim Alma Durumları ve} Görüşler

Katılımcılara "Lisans düzeyinde Türkçe öğretimi ve teknoloji kullanımıyla ilgili bir eğitim aldınız mı?" sorusu yöneltilmiştir. Tablo 9 sorulan soruya verilen cevaplar doğrultusunda oluşturulmuştur:

Tablo 9.

Türkçe Öğretmenlerinin Türkçe Öğretimi ve Teknoloji Kullanımıyla İlgili Eğitim Durumları

\begin{tabular}{lll}
\hline & $f$ & $\%$ \\
\hline Eğitimi Var & 7 & 14 \\
Eğitimi Yok & 43 & 86 \\
\hline Toplam & 50 & 100 \\
\hline
\end{tabular}

Araştırmaya katılan Türkçe öğretmenlerinden yalnızca 7'si lisans düzeyinde Türkçe öğretimi ve teknoloji kullanımı hususunda eğitim aldığını belirtmiştir. Bu konuda eğitim almadığını belirten 43 öğretmen bulunmakta ve bu öğretmenlerden çoğu günümüz koşullarında lisans düzeyinde böyle bir eğitim verilmesi gerektiği hususunda görüş bildirmektedir.

\subsection{0. Öğretmenlerin Salgın Dönemi Uzaktan Eğitimde Kullandıkları Programlar/Dijital Uygulamalara Yönelik Görüșler}

Katılımcılara yöneltilen " Salgın dönemi uzaktan eğitiminde kullandı̆̆ınız veya kullanmak zorunda kaldığınız programlar/dijital uygulamalar var mı? Bu uygulamaların Türkçe öğretimi açısından size katkıları oldu mu? Açıklayınız." sorusuna ait bulgular aşağıdaki şekildedir:

Tablo 10.

Türkçe Öğretmenlerinin Uzaktan Eğitimde Program/Dijital Uygulama Kullanımları

\begin{tabular}{lll}
\hline Kullanım Durumu & $f$ & $\%$ \\
\hline Var & 30 & 60 \\
Yok & 20 & 40 \\
\hline Toplam & 50 & 100 \\
\hline
\end{tabular}

Araştırmaya katılan Türkçe öğretmenlerinin \%60'ı uzaktan eğitim Türkçe derslerinde Zoom, Microsoft Teams ve EBA gibi programlar ve ders işlenişine fayda sağladığını düşündükleri dijital uygulamalar kullandıklarını belirtirken, \%40'ı hiçbir program kullanmadığını ifade etmiştir. Bu konuda belirtilen öğretmen görüşlerinden bazıları aşağıda verilmiştir.

Ö15. "Kullandığım uygulamalar var. Bu programlara uygun Türkçe içeriklerin ve derse uygun dijital materyallerin uzaktan eğitimle Türkçe öğretimine oldukça katkısı oldu." 
Ö22. "Evet, zorunlu olarak kullandığım uygulamalar oldu. Bu uygulamaları kullanırken yeterli düzeyde İngilizcemiz olmadığından çok zorlandık. MEB bu uygulamaları ya Türkçeleştirmeli ya da öğretmenlere yabancı dil eğitimi verilmesi taraftarıyım."

Ö25. "EBA, Morpa Kampüs gibi uygulamalar kullanıyorum. Bu uygulamaların Türkçe öğretimine katkısı oldu. Görsel ve işitsel duyulara hitap etmelerinin verimli olduğunu düşünüyorum."

Ö40. "Kullandığım uygulamalar var. Katkısı da oldu. Maalesef çok fazla dijital ortam sağlı̆ımı olumsuz etkiliyor."

Ö50. "Microsoft Teams uygulamasıyla dersimi anlattım. Bazı yayınların akıllı tahta uygulamalarını da bilgisayarıma indirerek oradan soru çözümleri yaptım. Çoğu uygulamaların Türkçe öğretimi açısından çok faydasını gördüm."

\subsection{1. Öğretmenlere Alanlarına Yönelik Teknoloji Eğitimi Verilmesine Dair Görüşler}

Araștırmaya katılan Türkçe öğretmenlerine, öğretmenlerin genel olarak ve kendi alanlarında teknoloji kullanımına yönelik neler yapılabileceği veya buna gerek olma durumu sorulmuştur. Öğretmenlerin bu konuda gereklilik hususunda verdikleri yanitlara göre Tablo 11 oluşturulmuştur.

Tablo 11.

Türkçe Öğretmenlerinin Teknoloji Kullanımına Yönelik Eğitimlerin Gerekliliğine Dair Görüșleri

\begin{tabular}{lll}
\hline Teknoloji Ĕ̈itimi & $f$ & $\%$ \\
\hline Gerekli & 41 & 82 \\
Gereksiz & 9 & 18 \\
\hline Toplam & 50 & 100 \\
\hline
\end{tabular}

Görüșlerine başvurulan Türkçe öğretmenlerinin \%82'si teknoloji alanında hizmet içi eğitim verilmesi hususunda görüş bildirmiştir. Hatta bazı öğretmenler bu eğitimlerin zorunlu olması gerektiğini dile getirmiştir. Teknoloji kullanımına yönelik eğitim gerekliliğine dair bazı öğretmen görüşleri şu şekildedir:

Ö1. "Yaşadığımız bölgede yerel anlamda sanal ağlar vasıtasıyla öğretimde deneyimlerin paylaşılmasl, öğretimde birliğin sağlanması ve yerel problemlerin çözülmesinde bilgi alışverişi yapılabilir."

Ö2. "Günümüzde teknoloji kullanımı bizler açısından hem bir zorunluluk hem bir gerekliliktir. Bunun için hizmet içi eğitimlere katılmalı ayrıca kendimizi geliştirmeliyiz."

Ö11. "Hizmet içi eğitim verilip derslerde kullanabileceğimiz içerikler fazlalaştırılabilir."

Ö15. "Gerekli ve faydalı olacağına inanıyorum. Cünkü teknoloji kullanımının yetersizliğinden dolayı zengin içerik sunamıyoruz."

Ö18. "Yeterli düzeyde, bütün öğretmenler teknolojiyi kullanıyor."

Ö28. "Konu ve derslerle alakalı oyun ve eğlence odaklı yazılımlar oluşturulabilir."

Ö36. "Teknoloji ilgi alanı bence bu konuyla ilgili olanlar kendisi araştırıyor. Alanımızla ilgili çok farklı bir uygulamaya gerek yok."

Ö38. "Öğretmenlerin bu eğitimleri kendilerinin dijital ortamdan alabileceklerini düşünüyorum. Kursların genel olarak çok verimli olmadığını düşünüyorum."

Ö39. "Dijital materyallere erişim için bir site, uygulama, blog veya platform oluşturulabilir. Bunlara her zaman gerek vardır."

\subsection{Türkçe Öğretmenlerinin Salgın Dönemi Uzaktan Eğitimde Yaşadı̆̆ı Sorunlar ve Çözüm Önerileri}

Araştırmaya katılan Türkçe öğretmenlerinden salgın dönemi uzaktan eğitimde yaşadıkları en önemli üç sorun ve bu sorunlara yönelik çözüm önerilerini yazmaları istenmiştir. Verilen yanıtlara bakıldığında internet bağlantı ve altyapı sorunları, çeşitli sebeplerle derslere katılımın çok az olması, öğrenci ilgisizliği, velilere uzaktan eğitimi açıklayamama, EBA platformundaki aksaklıklar, ders saatlerinin fazlalığı, teknoloji kullanımı hususundaki yetersizlikler, öğrenci ve öğretmenlerin donanım ve maddi yetersizlikleri gibi sorunlar öne çıkmaktadır. Bu sorunlar yalnızca Türkçe öğretimine yönelik değil genel sorunlar olarak görülmektedir. Özel okullarda göze çarpan en önemli problem ise velilerin okul idarelerine, öğrencilerinin kayıtlarını okuldan alacaklarını söylemeleri olmuştur. Genel olarak bahsedilen bir diğer sorun ise velilere uzaktan eğitimin ne olduğunu aktaramama problemidir. Öğretmenler, bazı öğrencilerin ailelerinin uzaktan eğitime karşı ilgisiz tutumundan dolayı öğrencilerin uzaktan eğitim sürecini tatil olarak gördüklerini ifade etmişlerdir.

Çalışmaya katılan öğretmenler bahsi geçen sorunlara yönelik çözüm önerileri olarak internet alt yapı problemlerinin çözülmesi, maddi yetersizliği olan öğrencilere MEB tarafından destek verilmesi, EBA içeriğinin zenginleștirilmesi, öğretmenlere teknoloji konusunda hizmet içi eğitim verilmesi, öğretmenlerin kişisel telefon numaraları yerine EBA'da mesajlaşma veya e-posta bölümünün oluşturulması, uzaktan eğitimden vazgeçilmesi başlıkları öne çıkmaktadır.

Aşağıda araştırmaya katılan Türkçe öğretmenlerinin bu soruya verdikleri yanıtlardan örnekler yer almaktadır.

Ö1. " Eğitim ve öğretim çalışmalarının uzaktan da yapılabileceği gerçeğini velilere bir türlü kabul ettirememek. Özel kurumlar olarak yüz yüze yapamadığımı öğretimden dolayı velilerin öğrencileri okuldan almakla ilgili tehditleri. Internet kesintileri ve alt yapı eksiklikleri." 
Ö2. "Öğrencilerin çoğunun çeşitli sebeplerle derslere katılmaması. Derse katılan öğrencilerin uzaktan eğitime gerekli ciddiyeti ve hassasiyeti göstermemesi. Uzaktan eğitim esnasında kontrolün zor olması. Uzaktan eğitim yeni deneyimlenen bir süreç oldu veliler ve öğrenciler için. Bu durumun önemini, faydalarını veya sağladı̆̆ imkanları önce velilere sonra öğrencilere iyi anlatmamız gerekir."

Ö4. "Sınıf ortamı: Sınıf atmosferinin oluşmaması. Denetim: Öğrencilerin sınıf ortamındaki kadar denetim altında tutulamaması. Suistimal: Öğrencinin çeşitli bahaneler sunarak derse katılmaması. Tek çözüm olarak yüz yüze eğitimi görüyorum."

Ö11. "Bağlantı sorunu: Şimdilerde durum daha iyi. Katılımın yeterince olmaması: Materyal ve internet kotası verilebilir. Ölçme değerlendirme sorunu: Her öğrencinin öğrenmesini ölçebilecek bir çözüm bulunabilir."

Ö15. "Derse katılımın az olması. Bu nedenle çok az öğrenciyle ders işlemek. Ödev takibi ve kitap okuma takiplerinin yapılamaması da büyük bir sorun. Sınıf içinde yapılan birçok etkinliğin uzaktan eğitimde yapılamaması nedeniyle somut öğrenmenin gerçekleşmemesi."

Ö28. "Öğrenciler arası firsat eşitsizliğini en temel sorun olarak görüyorum. Teknolojik imkanları olmayan öğrenciler uzaktan eğitimden yararlanamıyor. Velilerin teknoloji kullanımındaki eğitimsizlikleri. Veli ve öğrencilerin uzaktan eğitimi önemsememesi."

Ö36. "Ekonomik açıdan zor durumda olan öğrencilerin uzaktan eğitime teknolojik eksikliklerden dolayı katılamaması. Uzaktan eğitimin öğrenciye bir yaptırımının olmaması. Uzaktan eğitimi fırsat bilen velilerin öğrencileri işte çalıştırması."

Ö37. "Bilgisayar sıkıntısı çektim. Kendim bilgisayarın hard diskini değiştirdim ve ders materyali için internetten çeşitli sitelerden alışveriş yapmak zorunda kaldım."

Ö38. "EBA ve Zoom üzerinden sürekli atama yapmak: Bence bir tanesinden düzenli olarak yapılabilir. İnternet sıkıntısı yaşandı: Alt yapı güçlendirilmeli. Maddi sıkıntı içinde olan öğrencilerimiz var: Kaynak kitap desteği sağlanmalıydı."

Ö40. "Öncelikle ders saatleri çok fazla olduğu için teknolojik aletlerle çok fazla zaman geçirmek zorunda kalmak. Birtakım sebeplerden dolayı (internet sağlayıcısı ve yeterli internet olmaması) derslere katılım yeterli olmuyor."

0̈41. "Telefon numaramı tüm velilere vermek zorunda kalmam ve okuldan sınıflarımız için whatsapp grupları kurmamız gerektiğinin söylenmesi. Çözüm olarak EBA'da mesajlaşma veya mail bölümü olabilirdi. Veliler ve öğrenciler gece bile mesaj attı veya arama yaptı."

Ö47. "Donanım eksikliği: Öğrencilerin \%80'inde erişim sağlayacak materyaller az veya yok. İnternet erişimi: Çalıştığım mahallede çoğu telefon operatörünün çekim kalitesi düşük. İçerik azlı̆̆ı: Öğrencilerin maddi durumu yeterli olmadığı için daha az soru çözebiliyorlar. Kendi imkanlarım ile fotokopi çekip öğrencilere ulaştırlyorum."

\subsection{Türkçe Öğretmenlerinin Eklemek İstedikleri Hususlar}

Araştırmaya katılan öğretmenlerin eklemek istedikleri hususlardan örnekler aşağıda verilmiştir.

Ö1. "Toplumu karşllaşabilecekleri bazı sorunlarla ilgili nasıl hareket etmesi gerektiği konusunda bilinçlendirmek ve gerekirse eğitmek gerekmektedir. Sonuç olarak öğrencilere çeşitli bilgileri kazandırmak bu yolla mümkündür. "

Ö5. "Online eğitimde bilgiyi en üst düzeyde verebilirsin ancak duygu geçişi olmadığı için insan yetiştirmede online eğitim sağlıklı bir yöntem değildir. Online eğitim, çocuğun ya da bireyin yetişmesi açısından yetersiz bir platformdur."

Ö22. "Eğitimde başarı için bireysel çaba hiçbir zaman yeterli değildir. Şu salgın döneminde bile öğretmenler, veliler, öğrenciler kendi çabaları ile bir şeyler yapma gayreti içerisinde. Ama ne yazık ki bu şekilde başarı asla gelmez. Belki günü kurtarırız o da belki. Ĕger toplum olarak eğitimde başarılı olmak istiyorsak eğitimi siyasi kaygllardan uzak tutarak eğitimin paydaşlarının maddi imkanlarını artırma yoluna gitmeli, öğrencilere firsat eşitliği tanımalı, eğitim kurumlarının fiziki koşullarını iyileştirmeliyiz."

Ö46. "İlkokuldan başlayarak Word programında öğrencilere yazma çalışması yaptırılmalıdır. Bu teknoloji çağında teknolojinin dili ihmal edilmemelidir."

\section{SONUÇ VE ÖNERILER}

Geçmişten beri var olan uzaktan eğitim çalışmaları, tüm dünyada yaşanan salgından dolayı örgün eğitimin temel aracı hâline gelmiştir. Beklenmedik bir anda yüz yüze eğitime ara verilmek durumunda kalınması, uzaktan eğitime hızlı ve beklenmedik bir geçişe neden olmuştur. Türkiye'de Millî Eğitim Bakanlığına bağlı resmî ve özel okullarda 18 milyon civarında (MEB, 2020) öğrenci bulunduğu göz önüne alınırsa uzaktan eğitime geçişin ciddi bir hazırbulunuşluğu da beraberinde getirmesi gerekmiştir. Koronavirüs gibi bir salgının benzeri daha önce yaşanmadığından, olabileceklere karşı bir eğitim planının daha önceden var olmaması normal karşılanmalıdır. Ancak yaşanan bu salgın bize göstermiştir ki, beklenmedik kitlesel olaylar, doğal afetler ve salgınlara karşı eylem planı bulundurulmalıdır. Uzaktan eğitim bağlamında yapılan çalışmalar, içinde bulunduğumuz süreçte yaşanan sorunların belirlenmesi, çözüm önerilerinin bulunması ve dolayısıyla eğitim kalitesinin artırılması açısından önem arz etmektedir. Yapılan bu araştırmada uzaktan eğitimle sürdürülen Türkçe dersleri değerlendirilmeye çalışılmıştır.

Araştırmadan elden edilen verilere göre aşağıdaki sonuçlara ulaşılmıştır: 
Araştırma sonuçlarına göre uzaktan eğitimle yürütülen Türkçe derslerinde en çok zorlanılan beceri yazma becerisi ve ardından dil bilgisi öğrenme alanıdır. Uzaktan eğitim süreci öğrencilerin Türkçe dersine olan ilgilerini bazen olumlu bazen de olumsuz etkilemiştir. Uzaktan eğitim sürecinin öğrencilerin akademik başarısını olumsuz etkilediği görüşü hakim olsa da teknoloji kullanımına ilgi duyan öğrencilerin başarı düzey ve derse ilgilerinin arttığını gözlemleyen öğretmen sayısı azımsanamayacak derecededir. Araştırmaya katılan öğretmenlerin çoğu EBA Türkçe dersi içeriğini yeterli düzeyde bulmamış ve EBA'nın geliştirilmesi gerektiğini belirtmişlerdir. Uzaktan eğitimle yürütülen Türkçe derslerine katılım diğer derslerle aynı orandadır. Araştırmaya katılan öğretmenlerin beyanlarına göre, öğrencilerin uzaktan eğitime katılamamasının temel sebebi teknolojik yetersizlikler olarak görülmüştür. Bu nedenle derse katılım oranları arasında tutum ve ilgi yönünden belirleyici bir fark oluşması noktasına ulaşılamamıștır. Uzaktan eğitimle Türkçe öğretimi alanında yapılan çalışmalara bakıldığında "bilgisayar ve bağlantı eksikliği nedeniyle canlı derslere katılım sağlayamayan öğrencilerin çokluğunun katılan öğrencileri de olumsuz etkilediği" (Bayburtlu, 2020, s. 149) sonucuna ulaşılmıştır. Dolayısıyla tüm derslerde aynı durumun yaşandığı düşünülmektedir. Ayrıca katılımcı öğretmenler Türkçe ders kitaplarını uzaktan eğitime uygun bulmamışlardır. Türkçe öğretmenleri, koronavirüs salgını öncesinde \%90 oranla uzaktan eğitim tecrübesine sahip değildir. Araştırmaya katılan öğretmenlerin uzaktan eğitime dair herhangi bir eğitim alma durumları \%6'dır. Araştırmaya katılan öğretmenlerin \%60'ı ise kendini teknoloji kullanımı hususunda yetersiz bulmaktadır. Katılımcılardan yalnızca \%14'ü Türkçe eğitiminde teknoloji kullanımıyla ilgili eğitim almışlardır. Katılımcıların \%40'ı uzaktan eğitim yapılıyor olmasına rağmen hiçbir program veya dijital uygulama kullanmadığını belirtmiştir. Katılımcı öğretmenler \%82'lik bir oranla öğretmenlere teknolojiyle ilgili eğitim verilmesi gerektiğini düşünmektedir.

Verilen yanıtlara bakıldığında internet bağlantı ve altyapı sorunları, çeşitli sebeplerden ötürü derslere katılımın çok az olması, öğrenci ilgisizliği, velilere uzaktan eğitimin ne olduğunu anlatamama, EBA platformundaki aksaklıklar, ders saatlerinin fazlalı̆̆ı, teknoloji kullanımı hususundaki yetersizlikler öne çıkmaktadır.

Uzaktan eğitim sürecine ne zaman ihtiyaç duyulacağı ve şu anki sürecin ne zaman biteceği hususunda kesin bir kanaate varmak zor olduğundan, uzaktan eğitimin örgün eğitimi aksatmayacak şekilde düzenlenmesi gerekmektedir. Uzaktan eğitimin temel aracı olan teknoloji, öğrenci ve öğretmen açısından Millî Eğitim Bakanlığınca her yönüyle ele alınmalıdır. Halihazırda, maddi imkanları kısıtlı olan öğrencilere tablet dağıtımı yapılmaktadır ancak araştırmaya katılan öğretmenlerin ifadelerine bakıldığında, bunun yetersiz olduğu görülmektedir. Eğitimde fırsat eşitliğinin sağlanması adına ihtiyacı olan her öğrenciye tablet dağıtılması uzaktan eğitim sürecinde öğrencilerin mağdur olmasının önüne geçecektir. Öncelikle temel fizikî ihtiyaçlar giderilmeli ardından derslerde verimin artırılması için çalışmalar yapılmalıdır. Uzaktan eğitim canlı derslerine maddî imkânsızlıklardan dolayı giremeyen öğrencilerin akademik başarılarının sorgulanması doğru olmayacaktır. Bunlarla birlikte EBA içeriği sürekli güncellenmelidir. Öğretmenlerin, ihtiyaç duyduğu her alanda kendilerini geliştirmeleri adına, hizmet içi eğitimlere öncelik verilmelidir. Bu eğitim yüz yüze yapılabileceği gibi çevrim içi seminerler şeklinde de yapılabilir. "Çevrim içi seminerler öğretmenlerin bilgi ve öğretim becerilerini güncellemeleri için en son bilgileri sağladığından, bilişim teknolojilerinin hızla ilerlediği günümüzde, öğretimde yeni yöntem, yaklaşım ve teknikleri de sınıflarında uygulayabilmesini kolaylaştıracaktır" (Yıldız vd., 2020, s. 480). Ayrıca öğretmen yetiştirme sürecinde de, öğretmenlerin kendi alanlarında teknolojiyi etkin ve verimli kullanabilmelerini sağlamak amacıyla eğitimler verilmelidir.

Tüm bunların yanı sıra, Türkçe ders kitaplarının uzaktan eğitime uygun biçimde düzenlenmesi Türkçe eğitiminin daha sağlıklı yapılabilmesi adına faydalı olacaktır.

\section{KAYNAKÇA}

Banas, E. J., \& Emory, W. F. (1998). History and issues of distance learning. Public Administration Quarterly, 22(3), 365-383.

Bayburtlu, Y. S. (2020). Covid-19 pandemi dönemi uzaktan eğitim sürecinde öğretmen görüşlerine göre Türkçe eğitimi. Electronic Turkish Studies, 15(4), 149.

Bozkurt, A. (2017). Türkiye'de uzaktan eğitimin dünü, bugünü ve yarını. Açıöğretim Uygulamaları ve Araştırmaları Dergisi, 3(2), 85-124.

Bulut, K. (2020). Açı öğretim ortaokulu Türkçe ders kitaplarındaki metinlerin tür ve tema açısından incelenmesi. Ana Dili Ĕ̆itimi Dergisi, 8(3), 931-949.

Cresswell, John W. (2019). Eğitim araştırmaları: nicel ve nitel araştırmanın planlanması, yürütülmesi ve değerlendirilmesi. İstanbul: Edam Yayınları.

Demir, C., ve Yapıcı, M. (2007). Ana dili olarak Türkçenin öğretimi ve sorunları. Sosyal Bilimler Dergisi, 9(2), 177-192.

Güneş, F. (2009). Türkçe öğretiminde günümüz gelişmeleri ve yapılandırıcı yaklaşım. Mustafa Kemal Üniversitesi Sosyal Bilimler Enstitüsü Dergisi, 6(11), 1-21.

Harting, K., \& Erthal, M. J. (2005). History of distance learning. Information technology, learning, and performance journal, 23(1), 35.

MEB. (2019). Türkçe dersi öğretim programı (ilkokul ve ortaokul 1, 2, 3, 4, 5, 6, 7, 8.sınıflar). Ankara: Talim ve Terbiye Kurulu Başkanlığı. 
MEB, http://sgb.meb.gov.tr/meb iys dosyalar/2020 09/04144812 meb istatistikleri orgun egitim 2019 2020.pdf Erişim tarihi: 03/09/2021.

Mshvidobadze, T., \& Gogoladze, T. (2012). About web-based distance learning. International Journal of Distributed and Parallel Systems (IJDPS), 3(3), 133-143.

Sözbilir, M. (2009). Nitel Veri Analizi. Retrived from http://fenitay. files. wordpress. com/2009/02/1112-nitelarac59ftc4b1rmada-veri analizi. pdf on, 17, 2014.

Sumner, J. (2000). Serving the system: A critical history of distance education. Open Learning: The Journal of Open, Distance and e-Learning, 15(3), 267-285.

UNESCO, https://en.unesco.org/covid19/educationresponse. Erişim tarihi: 03/09/2021.

Valentine, D. (2002). Distance learning: Promises, problems, and possibilities. Online journal of distance learning administration, 5(3), 1-11.

Yıldız, C., Çakır, M., Başaran, B., \& Kaptı, Ü. (2020). Almanya'daki Türkçe öğretmenlerinin covid-19 salgını döneminde katıldığı çevrimiçi seminerlerle ilgili betimsel bir analiz. Diyalog Interkulturelle Zeitschrift Für Germanistik, 8(2), 457-487.

Yin, R. K. (2017). Durum çalışması araştırması uygulamaları. (Çev. İlhan Günbayı). Ankara: Nobel Akademik Yayıncılık. 